\title{
Comparative cytogenetics in Astyanax (Characiformes: Characidae) with focus on the cytotaxonomy of the group
}

\author{
Renata Cristina Claudino de Oliveira Tenório ${ }^{1}$, Carla de Andrade Vitorino ${ }^{1}$, \\ Issakar Lima Souza ${ }^{2}$, Claudio Oliveira ${ }^{3}$ and Paulo Cesar Venere ${ }^{1}$
}

Astyanax is a diverse group of Neotropical fishes, whose different forms occupy different environments. This great diversity is also reflected on cytogenetic aspects and molecular markers, which have repeatedly been demonstrated by cytogenetic studies. In order to characterize the karyotype of species of this genus, six species were studied: Astyanax altiparanae, A.argyrimarginatus, A. elachylepis, A. xavante, and two new species provisionally called Astyanax sp. and $A$. aff. bimaculatus. A detailed cytogenetic study based on conventional staining with Giemsa, AgNORs, C-banding, base-specific fluorochromes, and FISH using ribosomal genes $18 \mathrm{~S}$ and $5 \mathrm{~S}$ was conducted, aiming to understand some of the chromosomal mechanisms associated with the high diversification that characterizes this group and culminated with the establishment of these species. The results showed $2 n=50$ chromosomes for five species and a karyotype with 52 chromosomes in Astyanax sp. Small variations in the macrostructure of the karyotypes were identified, which were quite relevant when analyzed by classical banding, fluorochromes, and FISH methods. These differences among Astyanax spp. $(2 \mathrm{n}=50)$ are largely due to changes in the amount and types of heterochromatic blocks. Astyanax $\operatorname{sp}(2 \mathrm{n}=52)$, in addition to variations due to heterochromatic blocks, has its origin possibly by events of centric fission in a pair of chromosomes followed by minor rearrangements. These results show an interesting karyotypic diversity in Astyanax and indicate the need of a review of the group referred as $A$. aff. bimaculatus and the description of Astyanax sp., including the possibility of inclusion of this unit in another genus.

Astyanax é um grupo bastante diverso de peixes neotropicais cujas diferentes formas ocupam distintos ambientes. Esta grande variabilidade também se reflete em aspectos citogenéticos e moleculares, que têm sido repetidamente demonstrados por meio de estudos citogenéticos. A fim de caracterizar o cariótipo de representantes deste gênero, seis espécies foram estudadas: Astyanax altiparanae, A. elachylepis, A. xavante, A. argyrimarginatus e duas espécies novas provisoriamente citadas como Astyanax sp. e A. aff. bimaculatus. Um estudo citogenético detalhado com base na coloração convencional com Giemsa, AgNORs, banda C, fluorocromos base-específicos, e FISH com sondas para genes ribossomais $18 \mathrm{~S}$ e $5 \mathrm{~S}$ foi realizado com o objetivo de compreender alguns dos mecanismos cromossômicos associados com a alta diversificação que caracteriza este grupo de peixes e que culminou com o estabelecimento dessas espécies. Os resultados revelaram $2 \mathrm{n}=50$ cromossomos para cinco espécies e $2 \mathrm{n}=52$ cromossomos para Astyanax sp. Pequenas variações na macroestrutura dos cariótipos foram identificadas e se mostraram relevantes quando analisadas com base nos bandamentos clássicos, coloração por fluorocromos base-específicos e FISH com sondas de DNA $18 \mathrm{~S}$ e $5 \mathrm{~S}$. Esssa diversidade cariotípica detectada indica a necessidade de uma revisão taxonômica no grupo de indivíduos aqui referidos como A. aff. bimaculatus, inclusive com a descrição de Astyanax sp., incluindo a possibilidade de inserção dessa unidade em outro gênero distinto de Astyanax.

Key words: C-banding, $\mathrm{CMA}_{3}$ and DAPI fluorochromes, Fish chromosome, rDNA genes, NORs.

\footnotetext{
${ }^{1}$ Universidade Federal de Mato Grosso, Câmpus Universitário do Araguaia, Laboratório de Genética e Citogenética de Peixes - GEPEMA, ICBS, 78698-000 Pontal do Araguaia, MT, Brazil. pvenere@uol.com.br (PCV)

${ }^{2}$ Universidade Federal de Santa Catarina. Departamento de Biologia Celular, Embriologia e Genética. Câmpus Trindade. 88040-900 Florianópolis, SC, Brazil. issakar.souza@ufsc.br

${ }^{3}$ Universidade Estadual Paulista "Júlio de Mesquita Filho" (UNESP), Laboratório de Biologia e Genética de Peixes, Instituto de Biociências, 18618-970 Botucatu, SP, Brazil. claudio@ibb.unesp.br
} 


\section{Introduction}

Characiformes comprise the largest number of freshwater scaled fish known in the Neotropical region and Characidae is the largest and most complex family of this order. With 1.040 species (Eschmeyer \& Fong, 2013.), this fish family represents more than half of the species of Characiformes, and is a key component of Neotropical freshwater ecosystems (Oliveira et al., 2011). According to these authors, the composition, phylogeny, and classification of Characidae groups is currently uncertain, despite significant efforts based on analysis of morphological and molecular data have been undertaken.

According to Garutti \& Venere (2009), the last complete Astyanax revision founded on morphological characteristics was conducted by Eigenmann $(1921,1927)$, and the author who most recently treated this genus as a whole was Géry in 1977, who essentially followed Eigenmann. Astyanax is one of the most common genera in the freshwaters of Neotropical basins (Bertaco \& Garutti, 2007), and is non-monophyletic (Weitzman \& Fink, 1983; Garutti \& Venere, 2009; Mirande, 2010; Oliveira et al., 2011).

Astyanax corresponds to a larger taxonomic unit, with several species sharing similar forms which induce different authors to treat some units as "species complexes" (Moreira Filho \& Bertollo, 1991; Garutti \& Britski, 2000; Artoni et al., 2006). These fishes inhabit many different environments, including the waters from headwater streams, rivers, small and medium-sized lakes, and ponds, which seems to be one of the most important behavioral aspects that remains active in the establishment of the characteristics of species complexes of this genus.

Astyanax is the best cytogenetically studied genus of Characidae. The available data indicate an extensive chromosomal variability and a high degree of polymorphism among different species. However, analyzing the available information, it appears that many species have karyotypes with $2 \mathrm{n}=50$ chromosomes, as is the case of $A$. scabripinnis (Moreira-Filho \& Bertollo, 1991), A. altiparanae (Fernandes \& Martins-Santos, 2004; Ferreira-Neto et al., 2009), and $A$. laticeps (Rosa et al., 2009), among others.

Deviations from this value were reported for Astyanax schubarti, which reveals smallest chromosome number $(2 \mathrm{n}$ =36) described for the genus (Morelli et al., 1983, DanielSilva \& Almeida-Toledo, 2001, 2005); A parahybae with 2n = 48 chromosomes (Kavalco \& Moreira-Filho, 2003; Centofante et al., 2003), and A. fasciatus, which has karyotypes with $2 \mathrm{n}=45-48$ chromosomes (Pazza et al., 2006; Pazza et al., 2008a, 2008b).

It is possible to detect "species complexes" referring to three Astyanax groups, which show variation in relation to the diploid number and/or karyotype formula. In these complexes, there are outstanding species, such as $A$. scabripinnis (Moreira-Filho \& Bertollo, 1991) and A.fasciatus (Pazza et al., 2006), which show a great variation in both the karyotype macro structure and in the occurrence of supernumerary chromosomes, together with polymorphism in blocks of heterochromatin and nucleolar organizer regions (Souza et al., 2007). In A. altiparanae, these polymorphisms are also present, being primarily related to the micro and macrostructure of the karyotypes (Fernandes \& MartinsSantos, 2004). In this scenario, the cytogenetic data are potentially informative and, although the chromosomal variation is common among species, the mechanisms of fixation of chromosomal rearrangements or even the polarity of characters observed are still a matter of discussion.

Most current works have employed the FISH (fluorescence in situ hibridization) technique with different DNA probes to map the chromosomes, in an attempt to resolve cytogenetic dilemmas. This technique has enabled great progress in studies endeavoring to compare different fish species and/or populations (Teixeira et al., 2009; Vitorino et al., 2011; Martinez et al., 2012).

Another interesting issue relates to the fact that the $5 \mathrm{~S}$ rDNA sites are relatively more constant in number and location in contrast with the $45 \mathrm{~S}$ rDNA sites. These rDNA sequences occupy interstitial positions, meaning that they need to be most protected of the chromosomal rearrangements, while the $45 \mathrm{~S}$ rDNA locus are typically located in a terminal position on chromosomes, and thus most likely to undergo greater variability (Galetti Jr. \& Martins, 2004).

According to Nakajima et al. (2012) the presence of $5 \mathrm{~S}$ rDNA clusters in the interstitial or proximal position was frequently observed for some cichlids, as has previously been observed in several other fish groups. In this way, in relation to the number of these sites, in some cichlids species for example, the average cluster number per genome is slightly higher for $18 \mathrm{~S}$ rDNA, and the more intense dispersion of these genes seems to be related to their common presence in the terminal regions of the chromosomes. It can be related to the genomic dynamism of terminal regions of the chromosomes that could favor transposition events, leading to the dispersion of segments (Nakajima et al., 2012). Although it may occur in Astyanax species with 2 or $45 \mathrm{~S}$ rDNA sites (this paper) or even up to six of such sites in Piabina (Pazian et al., 2012), it seems that there is no standard mechanism that governs the behavior of these sites in different fish species studied so far.

Given the above, it is clear that there are many processes by which the karyotypes of fish may change. Each group can follow different paths, some of which are characterized by high rates of karyotypic diversification while others follow more conservative models in terms of diploid number, chromosome morphology, and banding patterns obtained by several techniques available. But the mechanisms of karyotypic diversification, especially in the genus Astyanax, still require many studies. Thus, based on an understanding of these mechanisms, it is believed that it is possible to effectively contribute to a good and broad regional characterization of fish diversicity, especially the ichthyofauna of the streams of the Cerrado bioma (savanna like) in the Central Brazil. 


\section{Material and Methods}

Six species of Astyanax were cytogenetically studied: $A$. altiparanae Garutti \& Britski, 2000 from Monjolinho stream (21 ${ }^{\circ} 59^{\prime} 9.26^{\prime}$ 'S 47 52'52.59”'W) (upper Paraná river basin); $A$. argyrimarginatus Garutti, 1999 from Jaraguá stream (15 56'27.18"S 52 $\left.2^{\circ} 15^{\prime} 18.68^{\prime \prime} \mathrm{W}\right)$; A aff. bimaculatus from Dois

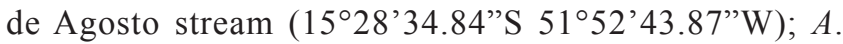
elachylepis Bertaco \& Lucinda, 2005 from Taquaralzinho stream (15'40'42”S 52 $\left.{ }^{\circ} 17^{\prime} 52^{\prime \prime} \mathrm{W}\right)$; A. xavante Garutti \& Venere, 2009 from Avoadeira stream (1551'19.66”'S 52 $\left.{ }^{\circ} 15^{\prime} 15.95^{\prime \prime} \mathrm{W}\right)$;

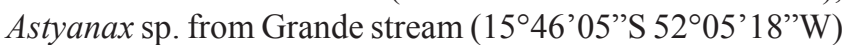
(Mortes river), all belonging to the Tocantins-Araguaia river basin (Fig. 1). Voucher specimens were deposited in the fish collection of the Laboratório de Biologia e Genética de Peixes (LBP) UNESP, Botucatu (São Paulo State, Brazil) (serial numbers LBP 17108-17115) and Campus Universitário do Araguaia, Universidade Federal de Mato Grosso, Brazil (serial number: ICLMA 635-640).

The specimens were anesthetized and sacrificed by cloveoil overdoses (Griffiths, 2000) and metaphasic cells were obtained through the air-drying technique (Bertollo et al., 1978; Foresti et al., 1993). C-banding, Ag-NORs, and fluorochrome staining with $\mathrm{CMA}_{3}$ and DAPI folowed Sumner (1972), Howell \& Black (1980) and Schweizer (1976, 1980), respectively. Fluorescent in situ hybridization (FISH) was applied to map $18 \mathrm{~S}$ and $5 \mathrm{~S}$ rDNA. The probes were labeled with 14-dATP biotin by nick translation, according to the manufacturer's instructions (Bionic Labeling System, Invitrogen). The metaphase chromosomes were treated according to the procedure described by Pinkel et al. (1986) and analyzed using an Olympus BX51 epifluorescence microscope. The chromosome images were captured using Olympus DP71 camera and the software Image Pro Express version 6.0 (www.mediacy.com). The final organization of the

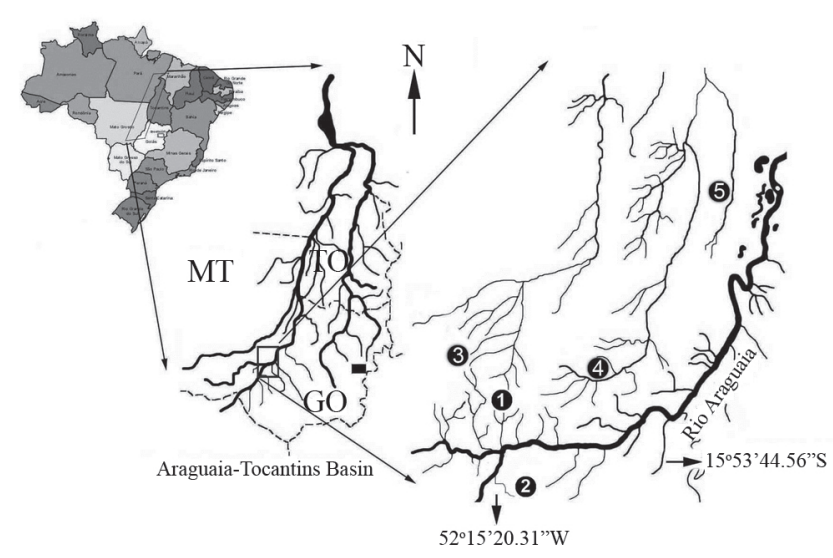

Fig. 1. Collection sites of Astyanax species in the Araguaia basin: (1) Avoadeira stream, (2) Jaraguá stream; (3) Taquaralzinho stream, (4) Grande stream, and (5) Dois de Agosto stream. karyotypes was based on their arm ratios, according to Levan et al. (1964), with adjustments for fish cytogenetics (Bertollo et al., 1978; Venere \& Galetti, 1989; Feldberg et al., 1993).

An idiogram was constructed for each species, aiming to summarize the data and facilitate their analysis together. After this step, the information obtained was used for the construction of a matrix of presence and absence, based on 157 characteristics, which were then used for a cluster analysis on the basis of similarities/dissimilarities, using the program Past (Cluster Analysis) based on Euclydean distances.

\section{Results}

The diploid number observed for five of the six species was equal to $2 \mathrm{n}=50$ chromosomes. Only Astyanax sp. revealed a divergent diploid number with $2 \mathrm{n}=52$ and a karyotype formula without the presence of acrocentric chromosomes (Fig. 2). Interspecific karyotypic changes, especially in relation to the amount of subtelocentric and acrocentric chromosomes, were observed among these species, with differences in fundamental numbers $(\mathrm{FN})$ ranging from 88 to 104 in A. elachylepis and Astyanax sp., respectively (Table 1).

AgNORs were mapped on the short arm of a mediumsized subtelocentric chromosome pair (st) in all species, which occupy different positions in the karyotypes. Besides that pair occupying different positions in the karyotypes analyzed, multiple sites of AgNORs were observed in Astyanax altiparanae and $A$. xavante (Fig. 2, box). However, FISH with $18 \mathrm{~S}$ rDNA probes confirmed a system of multiple NORs only for A xavante, which showed three pairs of chromosomes bearing rDNA sites (Fig. 2, box).

The constitutive heterochromatin distribution pattern (Fig. 3) proved to be species-specific, with some single blocks observed in each of the species studied. Most heterochromatic blocks were located in the pericentromeric and terminal position of the short arms of NOR-bearing chromosomes and in the interstitial regions of $\mathrm{m}, \mathrm{sm}$, and $\mathrm{st}$ chromosomes, mainly in Astyanax altiparanae, A. elachylepis and Astyanax sp. On the other hand, in A. xavante predominate telomeric heterochromatin, including a pair of acrocentric with large blocks of heterochromatin not observed in other species. A. aff. bimaculatus and A. argyrimarginatus presented reduced amount of heterochromatin restricted to the pericentromeric regions and associated with AgNOR sites.

$\mathrm{CMA}_{3}$ revealed that all blocks corresponding to the AgNORs sites bright more intensely after staining with this fluorochrome, suggesting they are $\mathrm{GC}^{+}$regions (Fig. 4).

In addition, several other constitutive heterochromatin blocks revealed to be $\mathrm{CMA}^{+}$, in opposition to the idea that this fluorochrome would be a good marker to identify only NOR-bearing chromosomes. It is worth emphasizing the large heterochromatic blocks detected in a pair of acrocentric chromosomes in Astyanax xavante, which is $\mathrm{CMA}_{3}{ }^{+}$and DAPI $^{-}$and are observed only in this species amongst all those species assessed in this work. 


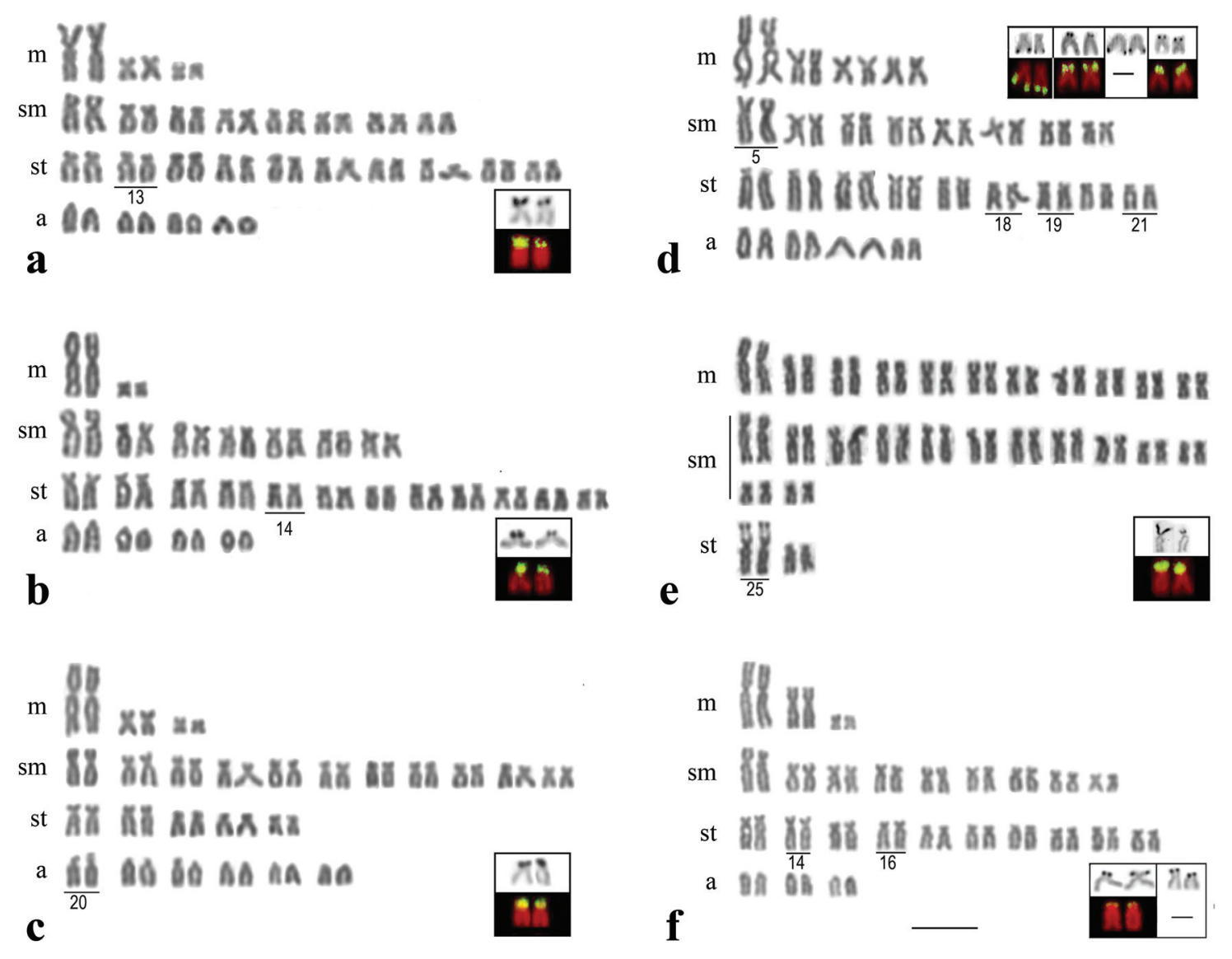

Fig. 2. Karyotypes of Astyanax argyrimarginatus (a), A. aff. bimaculatus (b), A. elachylepis (c), A. xavante (d), Astyanax sp. (e), and A. altiparanae (f), after conventional staining with Giemsa. Chromosomes carrying AgNORs and 18S sites (underlined in karyotypes) are highlighted in the box. Bar $=5 \mu \mathrm{m}$.

Also in relation to the DAPI fluorochrome (Fig. 5), another interesting event detected in this study was the presence of several interstitial AT-rich heterochromatic blocks, which were equilocally distributed among some chromosomes in Astyanax argyrimarginatus and in Astyanax sp. In both species, these DAPI-bright heterochromatic blocks were observed always in the interstitial region of the long arm, proximal to the centromere in submetacentric and subtelocentric chromosomes, and in the case of Astyanax sp., they were also observed in metacentric chromosomes. In A. argyrimarginatus, some less conspicuous blocks located in acrocentric chromosomes were also detected.

The localization of 5S rDNA genes revealed the occurrence of two pairs of chromosomes carrying these sites in Astyanax argyrimarginatus (submetacentric pair 5 and subtelocentric

Table 1. Studied species, number of specimens, diploid numbers and chromosome types observed in the six Astyanax species. $2 \mathrm{n}=$ diploid number, $\mathrm{NF}=$ fundamental number, $\mathrm{m}=$ metacentric, $\mathrm{sm}=$ submetacentric, $\mathrm{st}=$ subtelocentric and $\mathrm{a}=$ acrocentric.

\begin{tabular}{|c|c|c|c|c|c|c|c|c|c|c|c|c|}
\hline \multirow[t]{2}{*}{ Species } & \multicolumn{3}{|c|}{ n. ${ }^{\circ}$ of specimens } & \multicolumn{3}{|c|}{$\mathrm{n}^{\circ}$ of cells analized } & \multirow{2}{*}{$2 n$} & \multirow{2}{*}{ FN } & \multicolumn{4}{|c|}{ chromosomal types } \\
\hline & q & $\pi$ & total & q & $\hat{\sigma}$ & total & & & $\mathrm{M}$ & $\mathrm{sm}$ & st & $\mathrm{a}$ \\
\hline A. altiparanae & 15 & 10 & 25 & 390 & 60 & 450 & 50 & 94 & 6 & 18 & 20 & 6 \\
\hline A. argyrimarginatus & 14 & 12 & 26 & 90 & 150 & 240 & 50 & 92 & 6 & 16 & 20 & 8 \\
\hline A. aff. bimaculatus & 21 & 4 & 25 & 630 & 120 & 750 & 50 & 92 & 4 & 14 & 24 & 8 \\
\hline A. elachylepis & 12 & 8 & 20 & 180 & 240 & 420 & 50 & 88 & 6 & 22 & 10 & 12 \\
\hline A. xavante & 9 & 2 & 11 & 60 & 270 & 330 & 50 & 92 & 8 & 16 & 18 & 8 \\
\hline Astyanax sp. & 6 & 5 & 11 & 120 & 200 & 320 & 52 & 104 & 22 & 26 & 4 & - \\
\hline
\end{tabular}



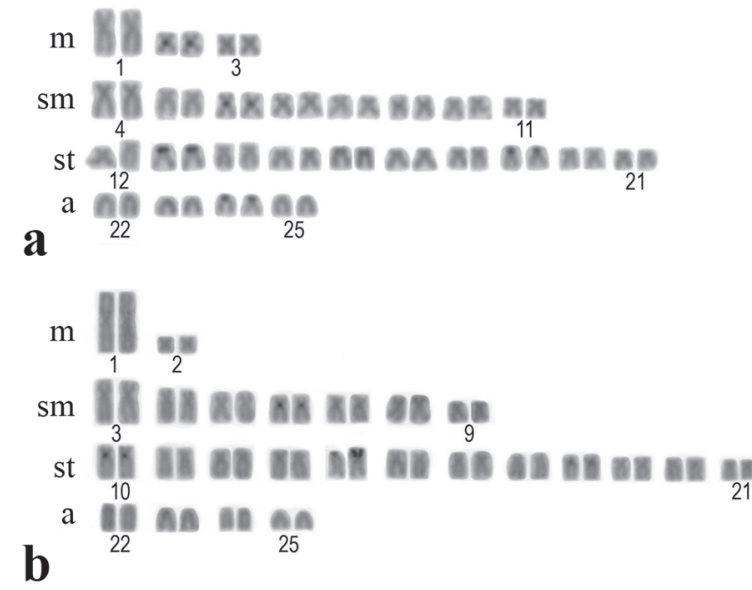

$m \int_{1} \times x \times x_{3}$

Sm

st $\frac{4}{15}$ XIA $8 X$ AL $\frac{\pi}{19}$

c

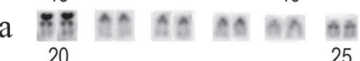

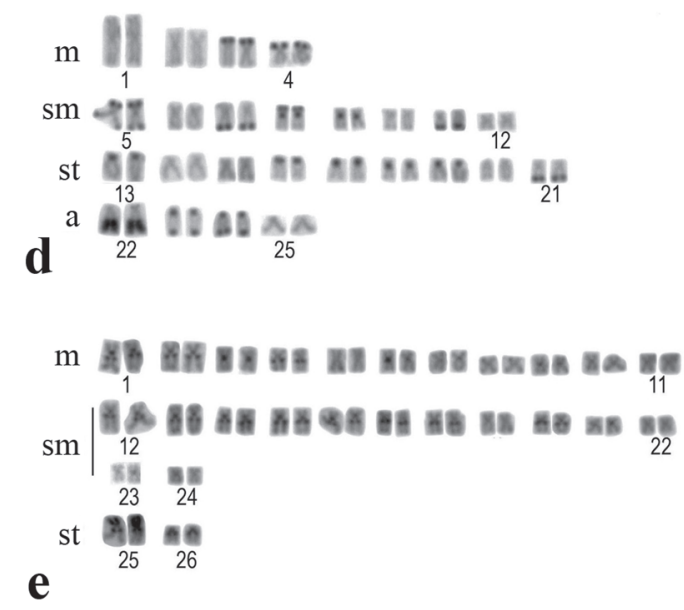

$\mathrm{m} \int_{1} x \mathrm{x} \mathrm{xa}_{3}$

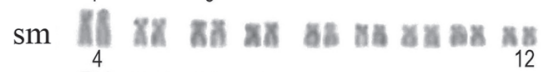

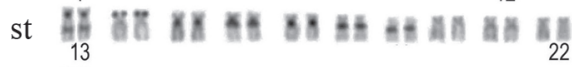

$f^{\text {a }} \prod_{23}$ at at at

Fig. 3. C-banded karyotypes of Astyanax argyrimarginatus (a), A. aff. bimaculatus (b), A. elachylepis (c), A. xavante (d), Astyanax sp. (e), and A. altiparanae (f). Bar $=5 \mu \mathrm{m}$.

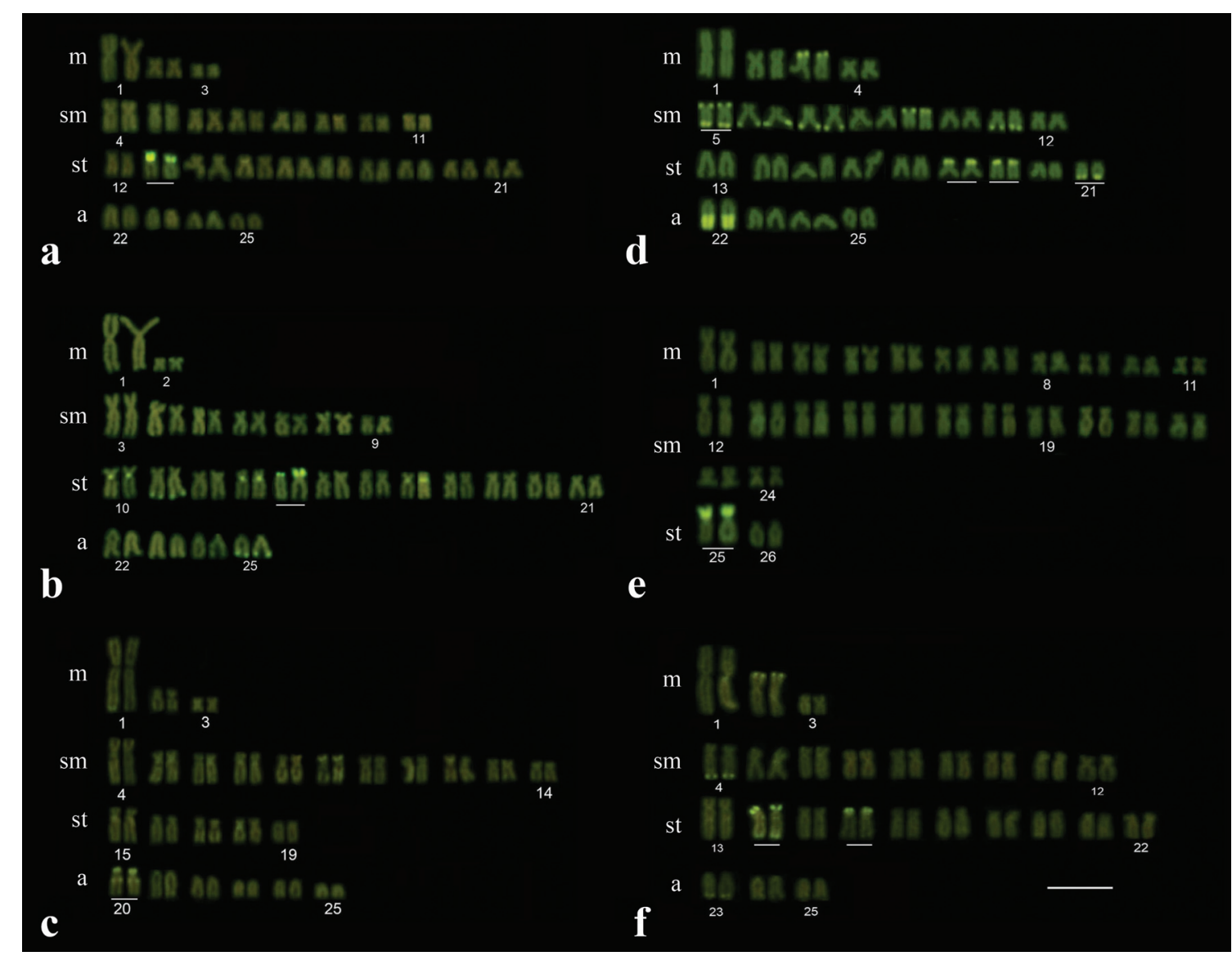

Fig. 4. $\mathrm{CMA}_{3}$ stained karyotypes of Astyanax argyrimarginatus (a), A. aff. bimaculatus (b), A. elachylepis (c), A. xavante (d), Astyanax sp. (e), and A. altiparanae (f). Chromosomes carrying AgNORs and 18S sites are underlined in karyotypes. Bar $=5 \mu \mathrm{m}$. 


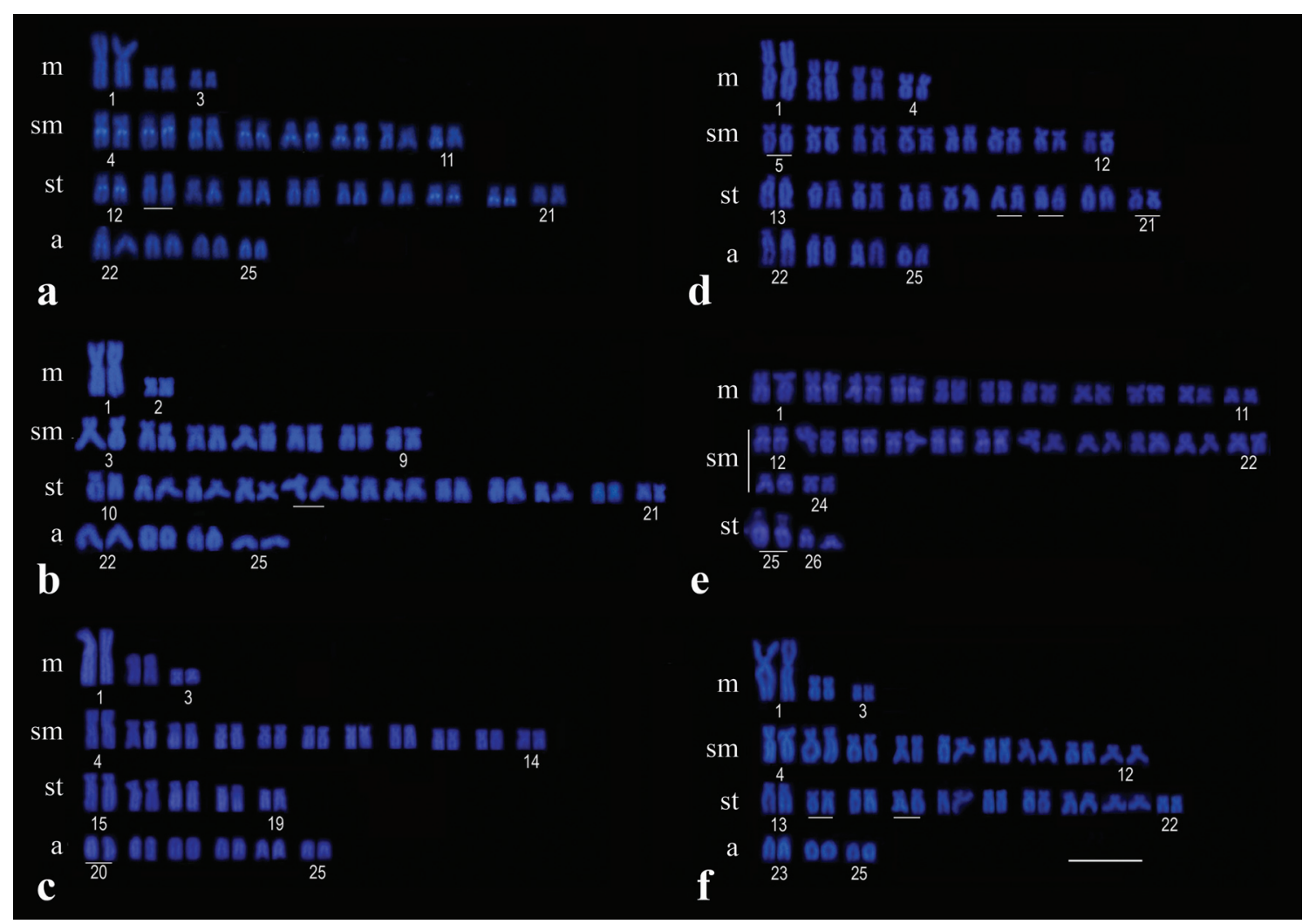

Fig. 5. DAPI stained karyotypes of Astyanax argyrimarginatus (a), A. aff. bimaculatus (b), A. elachylepis (c), A. xavante (d), Astyanax sp. (e), and A. altiparanae (f). Chromosomes carrying AgNORs and 18S sites are underlined in karyotypes. Bar $=5 \mu \mathrm{m}$.

pair 14), A. aff. bimaculatus (submetacentric pairs 4 and 5); Astyanax sp. (metacentric pair 2 and submetacentric pair 15), and $A$. altiparanae (submetacentric pairs 5 and 9). $A$. elachylepis and A.xavante have only one pair of chromosomes bearing these $5 \mathrm{~S}$ rDNA sites (submetacentric pairs 5 and 6 respectively) (Fig. 6).

For a better visualization of these results, an idiogram representing the haploid karyotypes of the six species with all techniques accomplished is showed in the Fig 7. The cluster analysis based on karyotypic characters enabled the construction of the dendrogram shown in Fig. 8.

\section{Discussion}

The diploid number of 50 chromosomes was observed in five species, while Astyanax sp. revealed $2 \mathrm{n}=52$. Fishes of the genus Astyanax usually possesses $2 \mathrm{n}=50$ chromosomes, with exceptions specially found in $A$. fasciatus with variations of $2 \mathrm{n}=45,46,47,48$, and 50 (Pazza et al., 2006; Ferreira-Neto et al., 2012) and A. scabripinnis (Moreira-Filho \& Bertollo, 1991). This large number of species and/or populations of Astyanax with 50 chromosomes, can be considered of great importance for conducting a kinship analysis, since this genus does not represent a natural group of species (Mirande, 2010; Oliveira et al., 2011).
Besides the diploid number, several other karyotypic characteristics apparently are shared among species of Astyanax. As an example, the metacentric chromosome pair number one seems to be an element shared by most species of this genus, except for Astyanax sp. (present paper), whose karyotype is being described for the first time. Another example can be seen in A.fasciatus, where this chromosome pair was observed with a smaller size (Pazza et al., 2008). A macrostructural analysis suggests that this chromosome pair is present in several species of other Characidae genera, suggesting that it represents a primitive feature in the family.

Another pair that seems to be shared by this genus refers to the main NOR-bearing chromosome (a medium-sized subtelocentric pair with NORs located on the short arm), that can be virtually seen in all species examined to date, including Astyanax sp. and in a NOR-bearing pair of A. xavante. Although their position may vary in different karyotypes, studies with fluorescent markers and FISH strengthens the idea that there is a strong similarity between these elements among the various karyotypes studied.

In this paper, differences in interspecific karyotypic macrostructures, especially with respect to the amount of subtelocentric and acrocentric chromosomes, were observed among the species of Astyanax, which is easily visualized only by the analysis of fundamental numbers, which ranged from 88 in A. elachylepis to 104 in Astyanax sp. 


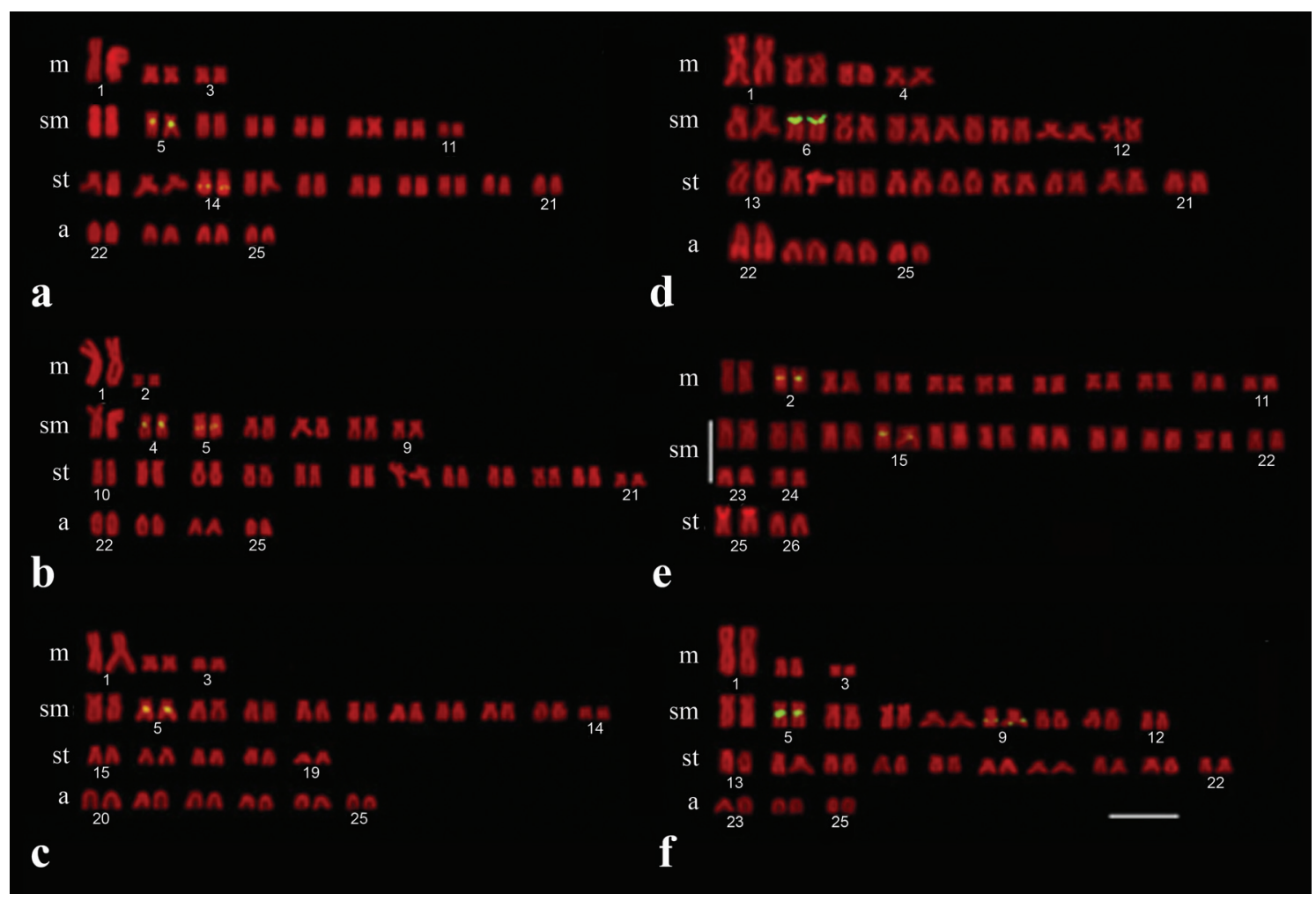

Fig. 6. Karyotypes of Astyanax argyrimarginatus (a), A. aff. bimaculatus (b), A. elachylepis (c), A. xavante (d), Astyanax sp. (e), and A. altiparanae (f) after FISH with 5S-DNA probes. Bar $=5 \mu \mathrm{m}$.

Such variations with changes in the fundamental numbers and without changes in the diploid numbers indicate that the karyotypic diversification in these groups of organisms are attributable to chromosomal rearrangements due to pericentric and paracentric inversions and/or translocations, which alter the morphology of chromosomes, but do not affect the diploid number. Kantek et al. (2007) assert that the variations detected in Astyanax sp. D from the Iguaçu River indicated the occurrence of chromosome polymorphisms in some of the homologous chromosome pairs, and that some of those variations were due to paracentric inversions detected by the C-banding technique.

The occurrence of such interpopulation variations in the karyotypic macrostructure in Astyanax can be partly explained by the biological characteristics of the species, such as the exploratory adaptive capacity (Orsi et al., 2002; Orsi et al., 2004), high feeding plasticity, reproductive capacity in various environment, preference for lentic waters and high phenotypic plasticity (Garutti \& Britski, 2000). These conditions favor the fixation of regional variations.

In addition to the studies based on Giemsa stained karyotypes, the AgNORs have been widely used as speciesspecific chromosomal markers for showing a relatively constant location within a species (Almeida-Toledo et al., 1998; Venere et al., 2008). The occurrence of AgNORs on a single pair of chromosomes (single AgNORs), as well as those distributed in several pairs (multiple AgNORs), are observed in different species of Astyanax: A. altiparanae with 4-7 reported sites (Pacheco et al., 2001; Daniel-Silva \& AlmeidaToledo, 2001; Fernandes \& Martins-Santos, 2004, 2006a, 2006b), A. scabripinnis with 4-14 sites (Mantovani et al., 2000; Mantovani et al., 2005; Fernandes \& Martins-Santos, 2005), A. fasciatus with four sites (Daniel-Silva \& Almeida-Toledo, 2001; Pazza et al., 2006), A. jacuhiensis with two sites (Pacheco et al., 2010), A. laticeps with three sites (Rosa et al., 2009), and $A$. giton with 10 and $A$. intermedius with 12 small reported sites (Kavalco \& Moreira-Filho, 2003).

Most cytogenetically analyzed species present only one pair of homologous NOR-bearing chromosomes. However, according to Pacheco et al. (2001), Souza et al. (2001); Jorge \& Moreira-Filho (2001), Almeida-Toledo et al. (2002); Mantovani et al. (2005), Fernandes \& Martins-Santos (2006a; 2006b), among others, the occurrence of multiple AgNORs is relatively common in some species and/or populations of Astyanax. Among the Astyanax species studied here, only $A$. xavante presented a system of AgNOR multiple sites, which were confirmed as bearers of NORs by FISH with $18 \mathrm{~S}$ rDNA probes.

In Astyanax jacuhiensis (Pacheco et al., 2010), A. laticeps (Rosa et al., 2009), and A.fasciatus (Ferreira-Neto et al., 2012), the multiple AgNOR systems were also confirmed by the FISH technique. In $A$. bimaculatus from the San Francisco, Doce, and Paraguay rivers, and in A. altiparanae from the Paraná 


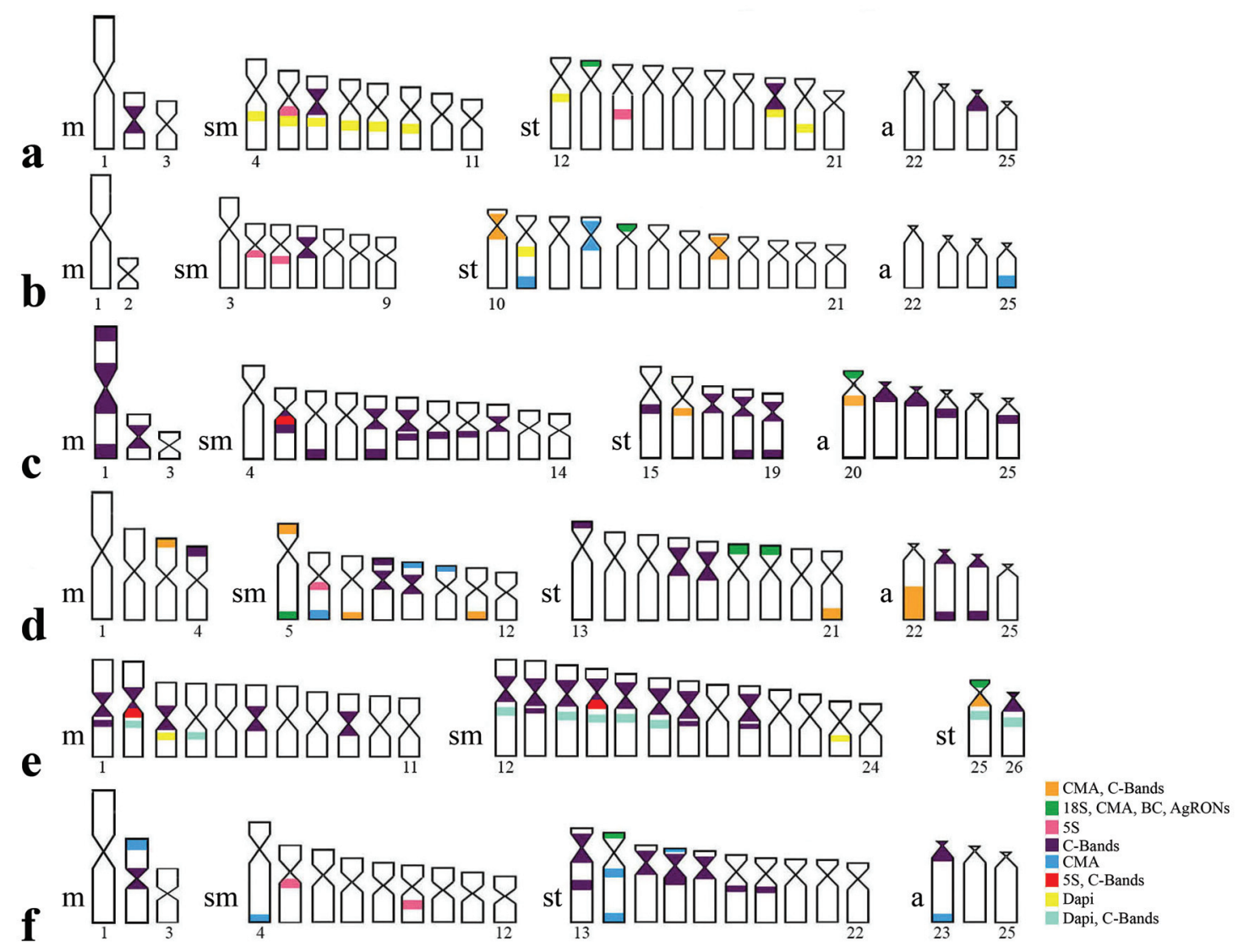

Fig. 7. Idiogram for the six studied Astyanax species with data obtained with different methodologies.

River (Fernandes \& Martins-Santos, 2004) and high Paraná (Stream Monjolinho), only a pair of AgNORs was evidenced (Peres et al., 2008). However, other studies with the same complexes have already reported the occurrence of multiple AgNOR systems in populations of other regions, which have not always been confirmed by the FISH technique.

The heterochromatin presents large amounts of highly repetitive DNA sequences in eukaryotic chromosomes. In this way, as the base pair composition of the constitutive heterochromatin is quite variable between species, basespecific fluorochromes have been useful for the characterization of different heterochromatic blocks. For this reason, the use of in situ hybridization with different rDNA probes has been refined enabling the characterization of distinct types of heterochromatin found in chromosomes of a given species (Sumner, 2003; Vicari et al., 2008).

The C-banding distribution pattern in the population of Astyanax aff. bimaculatus here studied corroborates the pattern found in A. jacuhiensis, A. altiparanae, A. fasciatus (Fernandes \& Martins-Santos, 2004; Pacheco et al., 2010) and $A$. bimaculatus. A. elachylepis, A argyrimarginatus, $A$. altiparanae, A. xavante, A. aff. bimaculatus and Astyanax sp. show species-specific characteristics, with banding patterns unique to each of them.
Similar occurrences were observed in Astyanax scabripinnis, where the constitutive heterochromatin pattern revealed to be one of the main features for discriminating populations (Moreira-Filho \& Bertollo, 1991). Another relevant fact is that $A$. xavante also revealed a pair of acrocentric chromosomes with large heterochromatic blocks, similar to that observed in A. scabripinnis (Souza, 1996; Mizoguchi \& Martins-Santos, 1998; Mantovani et al., 2004 among others).

Several of these heterochromatic blocks emerge as GCrich regions, which vary from species to species, proving to be quite useful for the analysis of the different karyotypes under study. Other GC-rich heterochromatin distribution patterns, which exhibit conspicuous blocks, especially in acrocentric chromosomes, and a diverse origin for different classes of heterochromatin were detected in Astyanax scabripinnis (Moreira-Filho et al., 1991; Souza et al., 2001), A. fasciatus (Pazza et al., 2008a, 2008b) and A.janeiroensis (Vicari et al., 2008).

Many of the bands produced by $\mathrm{CMA}_{3}$ are coincident with heterochromatic blocks in Astyanax aff. bimaculatus, and also in $A$. elachylepis, $A$. argyrimarginatus, $A$. altiparanae, A. xavante and Astyanax sp., mainly the pair of chromosomes associated with the AgNORs. There is a close relationship between the nucleolus organizer regions and the 


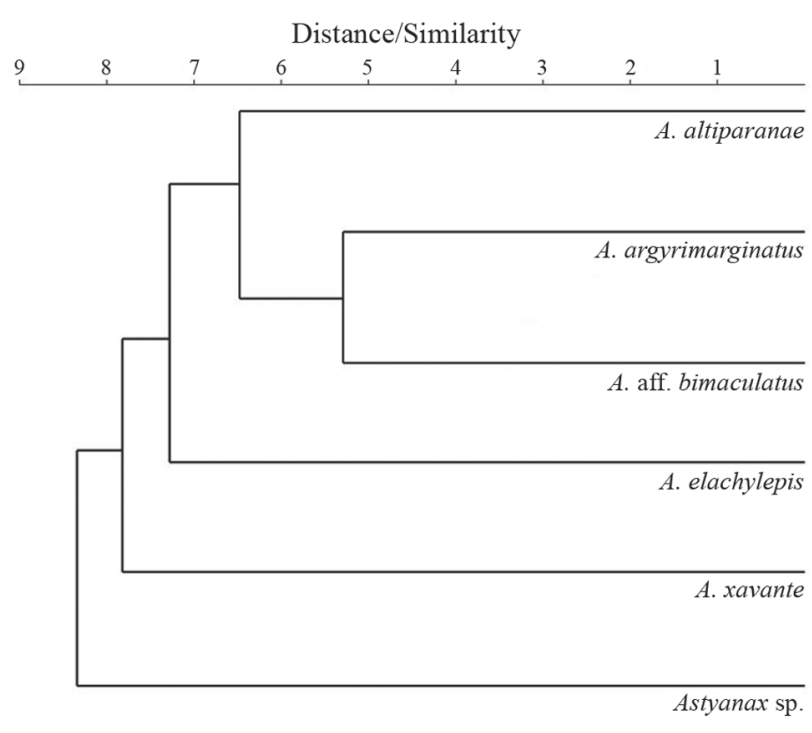

Fig. 8. Dendogram showing the karyotypic similarity obtained by cluster analysis and Euclydean distance coefficient among the six species of Astyanax studied.

GC-rich sites, and also with the heterochromatic blocks, although the staining with this specific GC fluorochrome cannot be considered a direct method for determining the location of ribosomal genes (Artoni et al., 1999). Nevertheless, this association has been relatively common among fish.

Interestingly, several heterochromatic $\mathrm{AT}^{+}$blocks were detected through this study after using the DAPI fluorochrome in the species Astyanax argyrimarginatus and Astyanax sp., with a localization pattern always maintained in the interstitial region of the long arm, next to the centromere of submetacentric and subtelocentric chromosomes. In the case of Astyanax sp., such localization patterns were found in metacentric chromosomes and less evident blocks in acrocentric chromosomes in A. argyrimarginatus.

Although the DAPI fluorochrome binds to both types of base pairs (GC and AT), its fluorescence is significantly enhanced by regions rich in AT base pairs and weakened in regions rich in GC base pairs (Lin et al., 1977). In fish, the occurrence of these bright bands is not common (Souza et al., 2008) and only negative bands coinciding with the $\mathrm{GC}^{+}$ bands are sometimes noticed, as observed in the first acrocentric chromosome pair in Astyanax xavante.

The 5S rDNA sites have proven to be variable among species, as some of which possess only one pair of chromosome bearers of these sites (Astyanax elachylepis and $A$. xavante) and others have two pairs (A. altiparanae, $A$. argyrimarginatus, A. aff. bimaculatus, and Astyanax sp.) occupying different positions on the karyotypes studied. Thus, the physical localization of these sites on chromosomes also represents an important cytotaxonomic marker, especially when analyzing groups of related species (Martins \& Galetti
Jr., 2001). In this way Martins \& Galetti Jr., (1999) analyzed the 5S rDNA of six species of Schizodon (Anostomidae), which proved to be highly conserved in two clusters, one larger and the other smaller in distinct chromosomes.

Based on the similarity dendrogram (Fig. 8) Astyanax aff. bimaculatus and $A$. argyrimarginatus, together with $A$. altiparanae, are a group of organisms karyotypically very similar. It is noteworthy that according to Garutti (1999), these species are associated with the A. bimaculatus complex. Thence, there is consistency between the karyotypic and taxonomic information.

The species Astyanax sp. demonstrated a lower degree of similarity compared to the other species, especially regarding the group composed of $A$. aff. bimaculatus, $A$. argyrimarginatus and $A$. altiparanae. A. xavante also showed high dissimilarity in comparison with the other species. $A$. elachylepis also appears with higher similarity with the group of species related to $A$. aff. bimaculatus.

The information provided in this study have proven important for the characterization of Astyanax species and could be further explored in a possible detailed taxonomic revision of the genus. Although the diploid numbers are conserved in the organisms studied (except for Astyanax sp.), the species showed significant differences either in the karyotypic macro- or microstructure, especially in the chromosomal banding pattern obtained through the different techniques, which allowed the detection of species-specific karyotypes for many of them. Astyanax sp. is the most distinct species and $A$. xavante holds several chromosomal characteristics (besides behavioral and morphological affinity) that make it more similar to the $A$. scabripinnis complex.

\section{Acknowledgments}

The authors are grateful to the brazilian agencies Conselho Nacional de Desenvolvimento Cientíco e Tecnológico (CNPq, process number 474057/2009-8), Fundação de Amparo à Pesquisa do Estado de Mato Grosso (FAPEMAT, process number 453511/2009 and 841147/2009) and CAPES. All catches were made in accordance with the licenses of SEMA (Case $\mathrm{n}^{\mathrm{o}}$ : 104358/2011/SEMA-MT) and Instituto Brasileiro do Meio Ambiente e Recursos Naturais Renováveis (MMA/IBAMA: license number 15226-1).

\section{Literature Cited}

Almeida-Toledo, L. F. 1998. Cytogenetic markers in Neotropical freshwater fishes. Pp. 583-588. In: Malabarba, L. R., R. E. Reis, R. P. Vari, Lucena, Z. M. Lucena \& C. A. S. Lucena (Eds.). Phylogeny and classification of neotropical fishes. Edipurs, Porto Alegre, Brasil.

Almeida-Toledo, L. F., C. Ozouf-Costaz, F. Foresti, C. Bonillo, F. Porto-Foresti \& M. F. Z. Daniel-Silva. 2002. Conservation of the 5S-bearing chromosome pair and colocalization with major rDNA clusters in five species of Astyanax (Pisces, Characidae). Cytogenetic and Genome Research, 97: 229-233. 
Artoni, R. F., W. F. Molina, L. A. C. Bertollo, P.M. Galetti Jr. 1999. Heterochromatin analysis in the fish species Liposarcus anisitsi (Siluriformes) and Leporinus elongatus (Characiformes). Genetics and Molecular Biology, 22: 39-44.

Artoni, R. F., O. A. Shibatta, M. C. Gross, C. H. Schneider, M. C. de Almeida, M. R. Vicari \& L. A. C. Bertollo. 2006. Astyanax aff. fasciatus Cuvier, 1819 (Teleostei; Characidae): evidences of a species complex in the upper rio Tibagi basin (Paraná, Brazil). Neotropical Ichthyology, 4: 197-202.

Bertaco, V. A. \& V. Garutti. 2007. New Astyanax from the upper rio Tapajós drainage, Central Brazil (Characiformes: Characidae). Neotropical Ichthyology, 5: 25-30.

Bertollo, L. A. C., C. S. Takahashi \& O. Moreira-Filho. 1978. Cytotaxonomic considerations on Hoplias lacerdae (Pisces, Erythrinidae). Revista Brasileira de Genética, 1: 103-120.

Centofante, L., L. A. C.Bertollo, A. J. Justi \& O. Moreira-Filho. 2003. Correlation of chromosomal and morphologic characters in two Astyanax species (Teleostei, Characidae). Ichthyological Exploration of Freshwaters, 14: 361-368.

Daniel-Silva, M. F. Z. \& L. F. Almeida-Toledo. 2001. Chromosome R-banding pattern and conservation of a marker chromosome in four species, genus Astyanax (Characidade, Tetragonopterinae).Caryologia, 54: 209-215.

Daniel-Silva, M. F. Z. \& L. F. Almeida-Toledo. 2005. Chromosome evolution in fish: BrdU replication patterns demonstrate chromosome homologies in two species of the genus Astyanax. Cytogenetic Genome Research, 109: 497-501.

Eschmeyer, W. N. \& J. D. Fong. 2013. Species by family/subfamily. Available at http://research.calacademy.org/research/ ichthyology/catalog/SpeciesByFamily.asp. Accessed 29 june 2013.

Feldberg, E., J. I. R. Porto \& C. M. Nakayama. 1993. Karyotype evolution in Curimatidae (Teleostei, Characiformes) from the Amazon region. II. Centric fissions in the genus Potamorhina. Genome, 36: 372-376.

Fernandes, C. A. \& I. C. Martins-Santos. 2004. Cytogenetic studies in two populations of the Astyanax altiparanae (Pisces, Characiformes). Hereditas, 141: 328-332.

Fernandes, C. A. \& I. C. Martins-Santos. 2005. Sympatric occurrence of three cytotypes and four morphological types of B chromosomes of Astyanax scabripinnis (Pisces, Characiformes) in the river Ivaí basin, state of Paraná, Brazil. Genetica, 124: 301-306.

Fernandes, C. A. \& I. C. Martins-Santos. 2006a. Mapping of the 18S and 5S ribosomal RNA genes in Astyanax altiparanae Garutti \& Britski, 2000 (Teleostei, Characidae) from the upper Paraná river basin, Brazil. Genetics and Molecular Biology, 29: 1-5.

Fernandes, C. A. \& I. C. Martins-Santos. 2006b. Chromosomal location of $5 \mathrm{~S}$ and $18 \mathrm{~S}$ rRNA genes in three sympatric cytotypes of Astyanax scabripinnis (Characiformes, Characidae) from the Ivaí river basin, state of Paraná, Brazil. Caryologia, 59: 253259.

Ferreira-Neto, M., R. F. Artoni, M. R. Vicari, O. Moreira-Filho, J. P. M. Camacho, M. Bakkali, C. Oliveira \& F. Foresti. 2012. Cytogenetics three sympatric karyomorphs in the fish Astyanax fasciatus (Teleostei, Characidae) do not seem to hybridize in natural populations. Comparative Cytogentics, 6: 29-40.

Ferreira-Neto, M., M. R. Vicari, E. F. Camargo, R. F. Artoni \& O. Moreira-Filho. 2009. Comparative cytogenetics among populations of Astyanax altiparanae (Characiformes, Characidae, Incertae sedis). Genetics and Molecular Biology, 32: 792-796.
Foresti, F., C. Oliveira \& L. F. Almeida-Toledo. 1993. A method for chromosome preparations from large fish specimens using in vitro short-term treatment with colchicine. Cellular and Molecular Life Sciences, 49: 810-813.

Galetti Jr., P. M. \& C. Martins. 2004. Contribuição da hibridização in situ para o conhecimento dos cromossomos de peixes. Pp. 61-88. In: Guerra, M. (Ed.). FISH: conceitos e aplicações na Citogenética. Ribeirão Preto: Sociedade Brasileira de Genética.

Garutti, V. 1999. Descrição de Astyanax argyrimarginatus sp. n. (Characiformes, Characidae) procedente da bacia do rio Araguaia, Brasil. Revista Brasileira de Biologia, 59: 585-591.

Garutti, V. \& H. A. Britski. 2000. Descrição de uma espécie nova de Astyanax (Teleostei: Characidae) da bacia do Alto rio Paraná e considerações sobre as demais espécies do gênero na bacia. Comunicações do Museu de Ciências e Tecnologia da PUCRS, Série Zoologia, 13: 65-88.

Garutti, V. \& P. C. Venere. 2009. Astyanax xavante, a new species of characid from middle rio Araguaia in the Cerrado region, Central Brazil (Characiformes/: Characidae). Neotropical Ichthyology, 7: 377-383.

Griffiths, S. P. 2000. The use of clove oil as an anaesthetic and method for sampling intertidal rockpool fishes. Journal of Fish Biology, 57: 1453-1464.

Howell, W. \& D. A. Black. 1980. Controlled silver-staining of nucleolus organizer regions with a protective colloidal developer: a 1-step method. Experientia, 36: 1014-1015.

Jorge, L. C. \& O. Moreira-Filho. 2001. Estudios citogenéticos en Astyanax bimaculatus (Pisces, Characidae) del río Paraná, Argentina. Revista de Ictiologia, 9: 21-24.

Kantek, D. L. Z., R. B. Noleto, A. S. Fenocchio \& M. M. Cestari. 2007. Cytotaxonomy, heterochromatic polymorphism and natural triploidy of a species of Astyanax (Pisces, Characidae) endemic to the Iguaçu River Basin (Paraná, Brasil). Brazilian Archives of Biology and Technology, 50: 67-74.

Kavalco, K. F. \& O. Moreira-Filho. 2003. Cytogenetical analysis in four species of the genus Astyanax (Pisces, Characidae) from Paraíba do Sul River Basin. Caryologia, 56: 453-461.

Levan, B. A., K. E. Fredga, H. A. Sandberg. 1964. Nomenclature for centromeric position on chromosomes. Hereditas, 52: 201-220.

Lin, M. S., D. E. Comings \& O.S. Alfi. 1977. Optical studies of interaction of 4'-6 diamidino-2-phenilindole with DNA and metaphase chromosomes. Chromosoma (Berl.), 60: 15-25.

Mantovani, M., L. D. S. Abel, C. A. Mestriner \& O. Moreira-Filho. 2000. Accentuated polymorphism of heterochromatin and nucleolar organizer regions in Astyanax scabripinnis (Pisces, Characidae): tools for understanding karyotypic evolution. Genetica, 109: 161-168.

Mantovani, M., L. D. S. Abel, C. A. Mestriner \& O. Moreira-Filho. 2004. Evidence of the differentiated structural arrangement of constitutive heterochromatin between two populations of Astyanax scabripinnis (Pisces, Characidae). Genetics and Molecular Biology, 27: 536-542.

Mantovani, M., L. D. S. Abel \& O. Moreira-Filho. 2005. Conserved $5 \mathrm{~S}$ and variable $45 \mathrm{~S}$ rDNA chromosomal localization revealed by FISH in Astyanax scabripinnis (Pisces, Characidae). Genetica, 123: 211-216.

Martinez, E., A. Alves, S. M. Silveira, F. Foresti \& C. Oliveira. 2012. Cytogenetic analysis in the incertae sedis species Astyanax altiparanae Garutti and Britzki, 2000 and Hyphessobrycon eques Steindachner, 1882 (Characiformes, Characidae) from the upper Paraná river basin. Comparative Cytogenetics, 6: 41-51. 
Martins, C. \& P. M. Galetti Jr. 1999.Chromosomal localization of 5S rDNA genes in Leporinus fish (Anostomidae, Characiformes). Chromosome Research, 7: 363-367.

Martins, C. \& P. M. Galetti Jr. 2001. Two 5S rDNA arrays in Neotropical fish species: is it a general rule for fishes? Genetica, 111: 439-446.

Mirande, J. M. 2010. Phylogeny of the family Characidae (Teleostei: Characiformes): from characters to taxonomy. Neotropical Ichthyology, 8: 385-568.

Mizoguchi, S. M. H. M. \& I. C. Martins-Santos. 1998. Cytogenetic and morphometric differences in populations of Astyanax "scabripinnis" (Pisces, Characidae) from Maringá region, PR, Brazil. Genetics and Molecular Biology, 21: 55-61.

Moreira-Filho, O. \& L. A. C. Bertollo. 1991. Astyanax scabripinnis (Pisces, Characidae): a species complex. Revista Brasileira de Genética, 14: 331-357.

Morelli, S., L. A. C. Bertollo, F. Foresti, O. Moreira-Filho \& S. A. Toledo-Filho. 1983. Cytogenetic considerations on the genus Astyanax (Pisces, Characidae). I. Karyotypic variability. Caryologia, 36: 235-244.

Nakajima, R. T., D. C. Cabral-de-Mello, G. T. Valente, P. C. Venere \& C. Martins. 2012. Evolutionary dynamics of rRNA gene clusters in cichlid fish. BMC Evolutionary Biology, 12: 198.

Oliveira, C., G. S. Avelino, K. T. Abe, T. C. Mariguela, R. C. Benine, G. Ortí, R. P. \& R. M. Corrêa e Castro. 2011. Phylogenetic relationships within the speciose family Characidae (Teleostei: Ostariophysi: Characiformes) based on multilocus analysis and extensive ingroup sampling. BMC Evolutionary Biology, 11: 275.

Orsi, M. L., E. D. Carvalho \& F. Foresti. 2004. Biologia populacional de Astyanax altiparanae Garutti \& Britski 2000 (Teleostei, Characidae) do médio rio Paranapanema, Paraná, Brasil. Revista Brasileira de Zoologia, 21: 207-218.

Orsi, M. L., O. A. Shibatta \& A. T. Silva-Souza. 2002. Caracterização biológica de populações de peixes do rio Tibagi, localidade de Sertanópolis. Pp. 425-432. In: Medri, M. E., Bianchini, E., Shibatta, O. A. \& Pimenta, J. A. A bacia do rio Tibagi. Londrina, Universidade Estadual de Londrina.

Pacheco, R. B., L. Giuliano-Caetano \& A. L. Dias. 2001. Occurrence of cytotypes and multiple NORs in an Astyanax altiparanae population (Pisces, Tetragonopterinae). Chromosome Science, 5: 109-114.

Pacheco, R. B., L. Giuliano-Caetano, H. F. Júlio Junior \& A. L. Dias. 2010. Cytogenetic data on Astyanax jacuhiensis (Characidae) in the lago Guaíba and tributaries, Brazil. Neotropical Ichthyology, 8: 667-671.

Pazian, M. F., L. H. G. Pereira, C. K. S.himabukuru-Dias, C. O. \& F. Foresti. 2012. Cytogenetic and molecular markers reveal the complexity of the genus Piabina Reinhardt, 1867 (Characiformes: Characidae). Neotropical Ichthyology, 10: 329-340.

Pazza, R., K. F. Kavalco, \& L. A. C. Bertollo. 2006. Chromosome polymorphism in Astyanax fasciatus (Teleostei, Characidae). 1- Karyotypic analysis, Ag-NORs and mapping of the 18S and $5 \mathrm{~S}$ ribosomal genes in sympatric karyotypes and their possible hybrid forms. Cytogenetic and Genome Research, 112: 313319.

Pazza, R., K. F. Kavalco \& L. A. C. Bertollo. 2008a. Chromosome polymorphism in Astyanax fasciatus (Teleostei, Characidae). 2 - Chromosomal location of a satellite DNA. Cytogenetic Genome Research, 122: 61-66.

Pazza, R., S. A. F. Kavalco, P. R. Penteado, K. F. Kavalco \& L. F. Almeida-Toledo. 2008b. The species complex Astyanax fasciatus
Cuvier (Teleostei, Characiformes) - a multidisciplinary approach. Journal of Fish Biology, 72: 2002-2010.

Peres, W. A. M., L. A. C. Bertollo \& O. Moreira-Filho. 2008.Physical mapping of the $18 \mathrm{~S}$ and $5 \mathrm{~S}$ ribosomal genes in nine Characidae species (Teleostei, Characiformes). Genetics and Molecular Biology, 31: 222-226.

Pinkel, D., T. Straume \& J. W. Gray. 1986. Cytogenetic analysis using quantitative, highsensitivity, uorescence hybridization. Proceedings of the National Academy of Sciences of the United States of America, 83: 2934-2938.

Rosa, R., M. Rubert, L. R. Malabarba, I. C. Martins-Santos \& L. Giuliano-Caetano. 2009. Cytogenetics analysis of Astyanax laticeps (Cope, 1894) (Ostariophysi: Characidae) from the laguna dos Patos system. Neotropical Ichthyology, 7: 601605.

Schweizer, D. 1976. Reverse fluorescent chromosome banding with Chromomycin and Dapi. Chromosoma (Berl.), 58: 307-324.

Schweizer, D. 1980. Simultaneous fluorescent staining of R bands and specific heterochromatic regions (DA DAPI-bands) in human chromosomes. Cytogenetics and Cell Genetics, 27: 190193.

Souza, I. L., P. M. Galetti Jr \& O. Moreira Filho. 1996. Heterochromatin differentiations in the characid fish Astyanax scabripinnis. Brazilian Journal of Genetics, 19: 405-410.

Souza, I. L., P. L. Rúa, J. Galián,; A. C. Bertollo \& O. Moreira Filho. 2001. Non-radom distribution of the GC-rich heterochromatin and nuclear rDNA sites on Astyanax scabripinnis chromosomes. Cytologia, 66: 85-91.

Souza, I. L.; L. K. Santos-Silva, P. C. Venere \& O. Moreira Filho. 2008. Molecular cytogenetics of Salminus fish (Characiformes) based on $5 \mathrm{~S}$ and $18 \mathrm{~S}$ rRNA genes hybridization, fluorochrome staining and C-banding. Micron (Oxford), 39: 1036-1041.

Souza, I. L., P. C. Venere \& O. Moreira-Filho. 2007. Constitutive heterochromatin and Ag-NOR polymorphisms in the small characid fish Astyanax scabripinnis (Jenyns, 1842). Cytologia, 72: 63-69.

Sumner, A. T. 1972. A simple technique for demonstrating centromeric heterochromatin. Experimental Cell Research, 75: 304-306.

Sumner, A. T. 2003. Chromosome organization and fuction. North Berwick, United Kingdom. Blackwell Publishing.

Teixeira, W. G., I. A. Ferreira, D. C. Cabral-de-Mello, J. Mazzuchelli, G. T. Valente, D. Pinhal, A. B. Poletto, P. C. Venere \& C. Martins. 2009. Organization of repeated DNA elements in the genome of the cichlid fish Cichla kelberi and its contributions to the knowledge of fish genomes. Cytogenetic and Genome Research, 125: 224-234.

Venere, P. C. \& P. M. Galetti Jr. 1989. Chromosome evolution and phylogenetic relationships of some Neotropical Characiformes of the family Curimatidae. Brazilian Journal of Genetics, 12: $17-25$.

Vicari, M. R., R. B. Noleto, R. F. Artoni, O. Moreira Filho \& L. A. C. Bertollo. 2008. Comparative cytogenetics among species of the Astyanax scabripinnis complex. Evolutionary and biogeographical inferences. Genetics and Molecular Biology, 31: 173-179.

Venere, P. C., I. L. Souza, L. K. S. Silva, M. B. Anjos, R. R. Oliveira \& P. M. Galetti Jr. 2008. Recent chromosome diversification in the evolutionary irradiation of the freshwater fish Curimatidae. Journal of Fish Biology, 72: 1976-1989. 
Vicari, M. R., R. F. Artoni, O. Moreira-Filho \& L. A. C. Bertollo. 2008. Colocalization of repetitive DNAs and silencing of major rRNA genes. A case report of the fish Astyanax janeiroensis. Cytogenetic and Genome Research, 122: 67-72.

Vitorino, C. A., I. L. Souza, J. N. Rosa, G. T. Valente, C. Martins \& P. C. Venere. 2011. Molecular cytogenetics and its contribution to the understanding of the chromosomal diversication in Hoplias malabaricus (Characiformes). Journal of Fish Biology, 78: 1239-1248.

Weitzman, S. H. \& W. L. Fink. 1983. Relationships of the neon tetras, a group of South American freshwater fishes (Teleostei, Characidae), with comments on the phylogeny of New World characiforms. Bulletin of the Museum of Comparative Zoology, Harvard University, 150: 339-395.

Submitted December 4, 2012 Accepted June 3, 2013 by Alexandre Hilsdorf Published September 30, 2013 